\title{
ŻYCIE KULTURALNE I NAUKOWE W ŁODZI NA ŁAMACH "DZIENNIKA ŁÓDZKIEGO" W LATACH 1945-1953
}

„Dziennik Łódzki” jako jeden z najstarszych polskich dzienników wydawanych w Łodzi, wciąż jest ważnym źródłem informacji o przeszłości miasta. Dotychczas gazeta była przedmiotem opracowań dotyczących bezpośrednio czytelnictwa polskiego ${ }^{1}$, o czym świadczy m.in. artykuł Jadwigi Koniecznej Zasługi „Dziennika Łódzkiego” dla upowszechniania polskiej książki w Ło$d z i w$ latach 1884-1892². Autorka, analizując zawartość gazety z tamtego okresu, przybliżyła szeroko pojętą problematykę książki prezentowaną na łamach „Dziennika Łódzkiego”, rozpoczynając od przeglądów nowości wydawniczych, recenzji, felietonów literackich, na reklamach i ogłoszeniach wydawnictw kończąc.

Obszerne monografie dotyczące „Dziennika Łódzkiego” to praca Zygmunta Gostkowskiego „Dziennik Łódzki” w latach 1884-1892³, która przedstawia wpływ i znaczenie, jakie gazeta wywarła na kształtowaniu opinii społecznej w Łodzi. Na rynku księgarskim ukazały się również dwie publikacje

${ }^{1}$ Więcej nt. prasy łódzkiej pisała m.in. W. Kaszubina, Czasopiśmiennictwo łódzkie w latach 1863-1914, „Rocznik Biblioteki Narodowej” 1970, t. 7, s. 207-245.

2 J. Konieczna, Zasługi „Dziennika Łódzkiego” dla upowszechniania polskiej książki w Łodzi w latach 1884-1892, „Acta Universitatis Lodziensis. Folia Librorum” 1997, t. 7, s. 3-24.

3 Z. Gostkowski, „Dziennik Łódzki” w latach 1884-1892. Studium nad powstaniem polskiej opinii społecznej w wielonarodowym mieście fabrycznym, Łódź 1963. 
podejmujące próbę ogólnej charakterystyki „Dziennika Łódzkiego”. Są to „Dziennik Łódzki” - tradycja i współczesność autorstwa Joanny Mikosz oraz „Dziennik Łódzki”: nasze 115-lecie ${ }^{5}$, której autorem jest Jacek Walicki. Wydawnictwa przybliżają historię powstania, kolejne przeobrażenia „Dziennika Łódzkiego", dziennikarzy i współautorów gazety oraz zagadnienia, jakim poświęcone były artykuły.

Archiwalne numery „Dziennika Łódzkiego” są doskonałym materiałem źródłowym. Niniejszy tekst stanowi analizę artykułów „Dziennika Łódzkiego" dotyczących szeroko pojętej kultury i nauki Łodzi. Wybrany przedział czasowy jest dla prasy okresem szczególnym, okresem działania w warunkach systemu uniemożliwiającego funkcjonowanie wolnych mediów w ich klasycznym kształcie. Wybór zakresu chronologicznego i treściowego, podyktowany był koniecznością ograniczenia analizy treściowej, jak i również szczególną sytuacją tego miasta w wybranym przedziale czasowym.

Wybuch II wojny światowej był dla Łodzi końcem pewnej epoki. Po zakończeniu walk miasto się zmieniło. Barwna i niepowtarzalna mozaika wyznań i narodowości zniknęła na zawsze. Zniszczone zostały pomniki kultury duchowej i materialnej m.in. Wielka Synagoga, Pałac Heinzla na Julianowie czy pomnik Tadeusza Kościuszki stojący na Placu Wolności. Ludność pochodzenia niemieckiego i żydowskiego była spotykana na ulicach coraz rzadziej. W mieście pozostało około 300000 mieszkańców z ogólnej liczby 672 000, która mieszkała tu w 1939 roku6 . Wyzwolenie Łodzi nastąpiło 19 stycznia 1945 roku, a już 25 stycznia 1945 roku w mieście ruszyły tramwaje, uruchomiono gazownię i elektrownię, które nie zostały uszkodzone w czasie walk. Do miasta szybko napływali ludzie ze wszystkich stron Polski. Pod koniec 1945 roku miasto liczyło około 422000 mieszkańców ${ }^{7}$.

Lata tuż po wojnie można uznać za okres pełnienia przez Łódź funkcji zastępczej stolicy Polski. Tu bowiem zgromadziły się przedstawicielstwa władz. Jeszcze w 1945 roku blisko czterokrotnie powiększono obszar miasta (do 21150 ha). Przez kilka lat Łódź pełniła również rolę stolicy kulturalnej Polski. Powstały szkoły, wyższe uczelnie, instytucje i placówki kultury, ośrodki naukowo-badawcze ${ }^{8}$.

\footnotetext{
${ }^{4}$ J. Mikosz, Dziennik Łódzki - tradycja i wspótczesność, Kalisz 2006.

${ }^{5}$ J. Walicki, Dziennik Łódzki: nasze 115-lecie, Łódź 1999.

${ }^{6}$ Powojenny pejzaż Łodzi, „Ilustrowana Encyklopedia Historii Łodzi. Lata powojenne czasy PRL” z. 11, s. 295-296.

7 Tamże.

8 Tamże.
} 
Niniejszy tekst nie rości sobie pretensji do pełnej analizy zawartości „Dziennika Łódzkiego” o życiu naukowym i kulturalnym Łodzi w latach 1945-1953. Jest raczej próbą stworzenia obrazu tamtejszych czasów, jaki prezentowany był przez jedną z najstarszych gazet łódzkich. Obraz ten jest niepełny, w pewnych kwestiach przejaskrawiony, co było skutkiem sytuacji politycznej kraju i ingerencji organów państwowych w funkcjonowanie wszelkich instytucji, w tym również i mediów.

Przedstawiony zakres chronologiczny łączy się z sytuacją panującą w kraju. Rok 1945 był początkiem nowej epoki nie tylko dla Łodzi, ale i dla całej Polski. Odbudowa zniszczonego wojną państwa, tworzenie nowego ładu i porządku w kraju, a co najważniejsze zmiana sytuacji politycznej to tylko niektóre z zadań, z jakimi musiała zmierzyć się „nowa” Polska. Data końcowa wystąpienia została podyktowana dwoma względami. Po pierwsze, jesienią 1953 roku zmieniona została nazwa „Dziennika Łódzkiego”. Na wniosek władz gazeta połączona została z „Expressem” i od tej pory funkcjonowała pod tytułem „Łódzki Express Ilustrowany”. Po drugie, i chyba najważniejsze, 5 marca 1953 roku umiera Józef Stalin. Jego śmierć oznacza koniec pewnej epoki dla Polski.

Lata 1945-1953 można uznać za nową fazę życia społeczeństwa, a co za tym idzie również i funkcjonowania mediów. Początkowe lata powojenne, do 1947 roku, dawały stosunkowo dużą swobodę życia politycznego. Prasa lokalna w tym okresie zachowywała pewne znamiona niezależności. Oczywiście istniała już cenzura prewencyjna i Biuro Kontroli Prasy, a od 1946 roku Główny Urząd Kontroli Prasy, Publikacji i Widowisk. Wraz ze zmianami politycznymi w latach 1947-1953, eliminacją opozycji i umacnianiem sił rządów komunistycznych następowała centralizacja systemu prasowego na wzór sowiecki.

W Łodzi po wojnie zaczął funkcjonować Wojewódzki Urząd Kontroli Prasy, Publikacji i Widowisk, który był jedną z szesnastu delegatur w kraju podległych Głównemu Urzędowi Kontroli w Warszawie (GUKPPiW powołany został dekretem Krajowej Rady Narodowej i Rady Ministrów 5 lipca 1946 roku). Niestety nie zachowały się akta osobowe łódzkich cenzorów, niewiele jest też źródeł dotyczących funkcjonowania oddziału. Dostępne są natomiast teczki z ingerencjami cenzorskimi oraz dzienne, tygodniowe i miesięczne raporty, w których cenzorzy oceniali łódzką prasę ${ }^{10}$. Pod kon-

${ }^{9}$ J. Mikosz, dz. cyt., s. 19.

${ }^{10}$ G. Mnich, Ingerencje cenzury w łódzkiej prasie codziennej (1949-1956) [w:] Urząd Miasta Łodzi [online], [dostęp: 04.07.2013]. Dostępny w WWW: http://uml.lodz.pl/get.php?id=4977 
trolą WUKPPiW był również „Dziennik Łódzki”. Ingerencja tej instytucji w treść gazety często zmieniała opisywaną rzeczywistość. Czytelnik nie zawsze mógł dostrzec, co jest prawdą, a co fałszem w zamieszczonym w gazecie artykule. Dziś po upływie ponad pięćdziesięciu lat wiemy, jak fałszowana była ówczesna rzeczywistość.

Tradycje prasy w Łodzi sięgają 1863 roku, kiedy to w mieście wydano pierwsze lokalne polsko-niemieckie pismo „Lodzer Anzeiger - Łódzkie Ogłoszenia” (znane bardziej jako „Lodzer Zeitung - Gazeta Łódzka”). Jednym z działów „Lodzer Zeitung” była polskojęzyczna Kronika, która w kwietniu 1881 roku została przekształcona w niezależny dodatek tygodniowy pod tytułem „Gazeta Łódzka”. Było to pierwsze łódzkie pismo w języku polskim, na łamach którego wypowiadać się mogła polska inteligencja. Swoje artykuły zamieszczała w nim m.in. Eliza Orzeszkowa czy Maria Szeliga. Gazeta wychodziła jedynie przez dwa miesiące, czyli do końca maja 1881 roku $^{11}$.

Trzy lata po upadku „Gazety Łódzkiej” miasto uzyskało samodzielny organ prasowy wydawany w języku polskim. 25 grudnia 1883 roku (według obowiązującego wówczas kalendarza prawosławnego, data pierwszego wydania to 6 stycznia 1884 roku) ukazał się pierwszy numer „Dziennika Łódzkiego” z podtytułem "pismo przemysłowe, handlowe i literackie”. Gazeta wydawana była przez Henryka Elzenberga - radcę prawnego firmy Scheiblera i jednocześnie współzałożyciela pisma „Niwa”. Jednak nominalnym wydawcą był Stefan Kossuth, naczelny inżynier w zakładach Scheiblera. Jak pisze Janina Jaworska „Dziennik Łódzki” był pismem inteligencji, kontynuował program warszawskiego pozytywizmu, szerzył kulturę polską w łódzkim środowisku wielonarodowym, zapoznając mieszkańców Łodzi z obyczajami, językiem i literaturą rodzimą (... $)^{12}$ ”. Jak widać „Dziennik Łódzki” od początku spełniał rolę gazety nie tylko informacyjnej, ale i w znacznej mierze kulturalnej.

Powojenny, pierwszy numer „Dziennika Łódzkiego” ukazał się 1 lutego 1945 roku i liczył cztery strony. Pierwszym redaktorem naczelnym gazety był, aż do 1950 roku, Anatol Mikułko - lekarz, poeta, dziennikarz, późniejszy redaktor „Dziennika Bałtyckiego” ${ }^{13}$. Kolejnymi redaktorami naczelnymi „Dziennika Łódzkiego” byli: Kazimierz Chmielewski, Wojciech Knittel

\footnotetext{
${ }^{11}$ J. Jaworska, Prasa [w:] Łódź, dzieje miasta, t. 1, do 1918 r., pod red. B. Baranowskiego, J. Fijałka, Warszawa 1980, s. 547.

12 Tamże.

${ }^{13} 19$ maja jego urodziny [w:] Warszawa - Naszemiasto.pl [online], [dostęp: 01.07.2013]. Dostępny w WWW: http://warszawa.naszemiasto.pl/artykul/19-maja-jego-urodziny,159879,art,t,id,tm.html
} 
i Franciszka Bzamowa ${ }^{14}$. Z upływem czasu gazeta zwiększyła swoją objętość do kilkunastu stron. Pod tytułem „Dziennik Łódzki” wychodziła do 1953 roku, kiedy to nakazem ówczesnych władz dziennik został połączony z „Expressem” pod wspólnym tytułem „Łódzki Express Ilustrowany”.

W latach 1945-1953 artykuły oraz informacje dotyczące życia kulturalnego zajmowały około jednej czwartej całości „Dziennika Łódzkiego”. Jak czytamy we wspomnieniach Adama Ochockiego: „Oczkiem w głowie pierwszego redaktora naczelnego, Anatola Mikułko (rozpoczynał pracę w mundurze kapitana), był dział kulturalny"15. Gazeta skupiała znakomitych eseistów, poetów, tłumaczy, dziennikarzy m.in. takich jak: Jerzy Wyszomirski ${ }^{16}$, Jan Huszcza ${ }^{17}$, Wiesław L. Brudziński, Michał Orlicz, Stanisław Woyna-Gwardziński, Stanisław Bal Chruszczewski ${ }^{18}$.

Stałą częścią gazety były repertuary łódzkich kin i teatrów, harmonogram wystaw muzealnych oraz szczegółowy program radiowy ${ }^{19}$.

Analizując wydania $\mathrm{z}$ wybranego przedziału czasowego, materiał można podzielić na kilka rodzajów.

Pierwszy z nich obejmował zagadnienia teatralne. Teatr zajmował w łódzkiej prasie lokalnej miejsce szczególne, a zagadnieniom z nim związanych poświęcano bardzo dużo uwagi. W gazecie zamieszczano na bieżąco recenzje teatralne m.in. sztuk takich jak: Bohaterowie dnia powszedniego wystawianego przez Państwowy Teatr Nowy ${ }^{20}$, Elektra w reżyserii Edmunda Wiercińskiego ${ }^{21}$, Pułkownik Foster przyznaje się do winy granego w Teatrze im. Jaracza ${ }^{22}$, operetki Dzwony $z$ Corneville, którą widzowie mogli obejrzeć

14 A. Ochocki, Erika zdradza tajemnice, Łódź 1989, s. 29-33.

15 Tamże, s. 27.

${ }^{16}$ Miał stały felieton, sygnował go kryptonimem „Wysz”, jak w latach międzywojennych w wileńskim „Słowie”, tamże, s. 28.

${ }_{17}$ Poeta, prozaik i tłumacz, używający pseudonimów Jan Olechno i Jan Zagościński, również jako etatowy pracownik publikował felietony o aktualnych zagadnieniach życia kulturalnego Łodzi. Tamże.

${ }^{18}$ Piszący pod pseudonimami: Zbigniew Morski, Roch Kowalski, Stanisław Bal, Stanisław Kempner.

19 Pierwsze numery „Dziennika Łódzkiego” nie zawierały programu radiowego, repertuar teatralnego czy kinowego. Dopiero w lipcu 1945 roku informacje te zaczęły być regularnie drukowane w gazecie. Znaleźć je można na ostatniej stronie „Dziennika Łódzkiego”, pod skróconym kalendarzykiem.

${ }^{20}$ S. Woyna-Gwaździński, „Bohaterowie dnia powszedniego” sztuka w trzech aktach Ewy Mandi, „Dziennik Łódzki” 1950, nr 248, s. 3.

${ }^{21}$ S. Sojecki, Wielka metafora, „Dziennik Łódzki”, 1946, nr 58, s. 3.

${ }^{22}$ „Pułkownik Foster przyznaje się do winy” na scenie Teatru im. Jaracza w Łodzi, „Dziennik Łódzki” 1953, nr 25, s. 4. 
w Teatrze Lutnia ${ }^{23}$. Z „Dziennika” czytelnicy dowiadywali się o zmianach organizacyjnych teatrów (np. zmianie statusu Teatru Wojska Polskiego z teatru lokalnego na teatr państwowy ${ }^{24}$ ), nowym dyrektorze Teatru im. Jaracza - Feliksie Żukowskim ${ }^{25}$ oraz mianowaniu Henryka Szletyńskiego na dyrektora Teatru Miejskiego w Łodzi ${ }^{26}$ czy aktorach pozyskanych przez teatry ${ }^{27}$. Jeden z dziennikarzy przedstawił czytelnikowi teatr zza kulis. Obszerny reportaż opisuje pracę osób, których goście teatru nie widzą: inspicjenta, oświetleniowca, perukarza i jak sam autor reportażu Władysław Orłowski napisał: „Ten reportaż zza kulis Państwowego Teatru Wojska Polskiego w Łodzi, ma właśnie uchylić rąbek tajemnicy, jaką dla szarego widza jest technika pracy w teatrze" 28 . W gazecie znaleźć można artykuły podsumowujące pracę łódzkich teatrów, takimi stwierdzeniami jak: „meteorem, który właśnie rozbłysł w Łodzi był piękny start młodego i naprawdę pod każdym względem teatru młodego typu awangardowej sceny łódzkiej Teatru Nowego”, „wejście na scenę łódzką takiej sztuki, jak Rodzina - sztuki pełniącej wielką rolę dydaktyczną - jest nowym wkładem w walkę o ideowe oblicze nowego, odrodzonego teatru"29. Na kartach gazety można znaleźć szkice i rysunki przedstawiające projekty planowanych w Łodzi teatrów np. Teatru Narodowego ${ }^{30}$.

Literatura i książka w ogólnym tego słowa znaczeniu to kolejny temat poruszany na stronach „Dziennika Łódzkiego”. Przeglądając ponad półwieczne numery gazety, możemy znaleźć artykuły na temat stanu literatury w Łodzi i jej szans na zaistnienie na świecie. Na łamach gazety wypowiadali się łódzcy literaci, informując o swoich planach twórczych na przyszłość na przykład Marian Piechal przyznał się do pisania tomu wierszy dla dzieci, który będzie nosił tytuł Podróże samolotem ${ }^{31}$. Gazeta żywo zachęcała do nabywania nowych książek. Służyły temu zaproszenia do nowo powstających w Łodzi księgarńn ${ }^{32}$ i streszczenia nowości wydawniczych. Na łamach „Dziennika” triumfy w upowszechnianiu książki wśród czytelników święci-

${ }^{23}$ M. Piechal, Dzwony z Corneville, „Dziennik Łódzki” 1949, nr 130, s. 3.

${ }_{24}$ Z. Morski, L. Schiller obejmuje dyrekcję teatru w Łodzi, „Dziennik Łódzki” 1946, nr 122, s. 3.

25 T. Wojciechowska, Wywiad ze „starym” aktorem i „młodym” dyrektorem Feliksem Żukowskim, „Dziennik Łódzki” 1953 nr 14, s. 4; Feliks Żukowski dyrektorem Teatru im. Jaracza w Łodzi, „Dziennik Łódzki” 1953, nr 13, s. 4.

${ }_{26}$ Polpress, Szletyński dyrektorem Teatru Miejskiego, „Dziennik Łódzki” 1945, nr 8, s. 3.

27 Z. Nowicki, Zmiany w teatrach łódzkich, „Dziennik Łódzki” 1947, nr 15, s. 3.

${ }_{28}$ W. Orłowski, O sprawach niedostrzegalnych dla publiczności. Za kulisami Teatru WP w Ło$d z i .$, „Dziennik Łódzki” 1948, nr 26, s. 2.

${ }^{29}$ Z. Nowicki, Stary i nowy rok teatralnej Łodzi, „Dziennik Łódzki” 1951, nr 3, s. 3.

30 „Dziennik Łódzki” 1951, nr 14, s. 4.

${ }_{31}$ Na naszych warsztatach pisarskich, „Dziennik Łódzki” 1953, nr 1, s. 4.

32 Specjalne księgarnie naukowe Domu Książki, „Dziennik Łódzki” 1951, nr 14, s. 4. 
ła Spółdzielnia Wydawniczo-Oświatowa „Czytelnik”. W gazecie ukazywały się ogłoszenia o nowych seriach wydawniczych „Czytelnika” np. Biblioteka Romansów i Powieści. Informowano też o działalności punktów bibliotecznych „Czytelnika” 33 , opisywano obszernie zasługi wydawnictwa dla kultury $^{34}$. Oprócz krótkich ogłoszeń w formie „ramek”, w gazecie ukazywały się obszerne artykuły przybliżające tematykę serii wydawniczych Spółdzielni Wydawniczo-Oświatowej „Czytelnik”, po to, aby każdy mógł wybrać książkę zgodnie ze swoimi zainteresowaniami ${ }^{35}$. Na kartach gazety "Czytelnik” dziękował wszystkim „członkom, pracownikom i sympatykom” za współpracę oraz zachęcał do „współzawodnictwa w wykonaniu planu” na lata następne ${ }^{36}$.

Książki propagowano także poprzez zamieszczanie krótkich informacji o wystawach książek w bibliotekach łódzkich ${ }^{37}$, nakłanianie czytelników do stworzenia własnej biblioteki domowej ${ }^{38}$ czy za pomocą haseł np. o treści „Czytaj książki”, które można było znaleźć pomiędzy artykułami. Gazeta żywo zachęcała do „ratowania od dalszego zniszczenia resztek ocalałych książek polskich" poprzez systematyczne oddawanie wypożyczonych książek do bibliotek oraz zwrot książek wypożyczonych przed II wojną światową ${ }^{39}$.

$\mathrm{Z}$ czasem upowszechniania się filmu i rosnącej popularności kin, na łamach "Dziennika Łódzkiego" coraz więcej informacji dotyczyło sztuki filmowej. Początkowo były to krótkie wzmianki o premierach kinowych, aby z czasem przejść do obszerniejszych opisów. Oprócz zamieszczanych codziennie repertuarów kin, w gazecie pojawiały się recenzje filmowe np. filmu produkcji radzieckiej pt. Czwarty perysko $p^{40}$ czy produkcji francuskiej Jej pierwszy bal ${ }^{41}$. Drukowane były afisze filmowe informujące o nowościach kinowych oraz o tematycznych pokazach filmowych (np. Wyświetlanie filmów radzieckich w 1948 roku $^{42}$ ), informacje o ogólnopolskich zjazdach Ki-

${ }^{33}$ Z. Petersowa, Jak pracuja z ksią̇ką punkty biblioteczne „Czytelnika”, „Dziennik Łódzki” 1949, nr 134, s. 3.

34 B. Czyżewicz, Działalność kulturalna „Czytelnika, „Dziennik Łódzki” 1946, nr 13, s. 6.

${ }_{35}$ M. Piechal, Biblioteka „Wiedzy Powszechnej”, „Dziennik Łódzki” 1948, nr 1, s. 9.

${ }^{36}$ Podziękowania od „Czytelnika” ukazywały się w latach 1947-1949. Informacja zajmowała jedną stronę gazety, na której informowano o wydaniu w roku ubiegłym serii wydawniczych, działalności klubów książki, ilości wydawanych dzienników i czasopism przez Spółdzielnię. „Dziennik Łódzki” 1947 nr 1, s. 3; 1948, nr 1, s. 3; 1949, nr 1, s. 3.

37 Wystawy książek w bibliotekach łódzkich, „Dziennik Łódzki” 1946, nr 120, s. 5.

${ }^{38}$ Jak skompletować wtasną bibliotekę, „Dziennik Łódzki” 1949, nr 105, s. 4.

39 Ratujmy książkę polską, „Dziennik Łódzki” 1945, nr 9, s. 4.

40 „Czwarty peryskop” (produkcja radziecka), „Dziennik Łódzki” 1949, nr 98, s. 3.

${ }^{41}$ „Jej pierwszy bal” (produkcja francuska), „Dziennik Łódzki” 1948, nr 101, s. 3.

42 „Dziennik Łódzki” 1948, nr 114, s. 5. 
nooperatorów ${ }^{43}$ czy artykuły dotyczące działalności np. wytwórni „Filmu Polskiego" w Łodzi ${ }^{44}$.

Muzyka to kolejne zagadnienie, które na stałe zagościło na łamach „Dziennika Łódzkiego”. Gazeta informowała o planowanych występach w Łodzi znanych zespołów, pieśniarzy lub muzyków m.in. pianisty Zbigniewa Drzewieckiego ${ }^{45}$, skrzypka Władysława Wochniaka ${ }^{46}$. Zamieszczono również artykuły o nagrodach przyznawanych łódzkim muzykom, audycjach słowno-muzycznych organizowanych w ramach akcji upowszechniania muzyki dla mieszkańców Łodzi ${ }^{47}$ czy koncertach organizowanych w sali „Czytelnika”"4. Bardzo dużo miejsca poświęcano łódzkiej filharmonii. Informowano m.in. o wznowieniu działalności filharmonii po przejęciu jej przez władze miejskie ${ }^{49}$, o remoncie Sali Filharmonii przy ul. Narutowicza ${ }^{50}$, organizowanych porankach muzyki ludowej ${ }^{51}$, koncertach światowych sław m.in. Zdzisława Górzyńskiego ${ }^{52}$. Zamieszczano obszerne relacje $\mathrm{z}$ odbytych koncertó $\mathrm{w}^{53}$ lub zaproszenia na koncerty ${ }^{54}$. W gazecie pisano również o akcjach propagujących muzykę wśród mieszkańców miasta. Stanisław Woyna-Gwiaździński w artykule z 1951 roku przybliża akcję grupy „Artos”, która koncertowała w świetlicach zakładowych przemysłu bawełnianego. Pracownicy zakładów mogli wysłuchać kompozycji muzyki klasycznej w wykonaniu takich artystów jak: Halina Mickiewiczówna, Jerzy Gawryluk czy Stanisław Urstein ${ }^{55}$.

Łódzcy plastycy w drugiej połowie XX wieku byli prężnie działającą grupą, której dokonania na bieżąco były odnotowywane w „Dzienniku Łódzkim”. Gazeta informowała o: wystawach plastyków, m.in. na odbywającej się w 1951 roku VI Dorocznej Wystawie Prac Łódzkich Artystów-Plastyków

${ }^{43}$ Zjazd kinooperatorów odbyt się w Łodzi, „Dziennik Łódzki” 1948, nr 63, s. 5.

${ }^{44}$ Cisza! Zdjęcia! Wytwórnia „Filmu Polskiego” w Łodzi przy pracy, „Dziennik Łódzki” 1946, nr 154, s. 3.

${ }^{45}$ Zbigniew Drzewiecki w Filharmonii, „Dziennik Łódzki” 1946, nr 9, s. 6.

46 Władysław Wochniak w Filharmonii, „Dziennik Łódzki” 1949, nr 144, s. 3.

${ }^{47}$ Bezpłatna audycja muzyczna, „Dziennik Łódzki” 1948, nr 111, s. 5.

48 Popularne koncerty „Czytelnika”, „Dziennik Łódzki” 1946, nr 21, s. 5.

${ }^{49}$ Lepiej późno, niż nigdy. Filharmonia Łódzka rozpoczyna sezon koncertowy, „Dziennik Łódzki" 1948, nr 48, s. 3.

50 Jotes, Filharmonia łódzka czeka na nowy gmach, „Dziennik Łódzki” 1946, nr 119, s. 7.

51 T. Sivert, Poranek muzyki ludowej w Filharmonii Łódzkiej, „Dziennik Łódzki”

52 T. Sivert, Górzyński i Czerny-Stefańska w Filharmonii Łódzkiej, „Dziennik Łódzki” 1949, nr 99, s. 3.

${ }^{53}$ T. Sivert, Muzyczna wieża Babel, „Dziennik Łódzki” 1948, nr 136, s. 3.

${ }^{54}$ Koncert Wielkoczwartkowy w Filharmonii, „Dziennik Łódzki” 1949, nr 101, s. 3.

55 S. Woyna-Gwiaździński, Muzycy w zakładach pracy, „Dziennik Łódzki” 1951, nr 14, s. 4. 
w salach Ośrodka Propagandy Sztuki ${ }^{56}$, udziale łódzkich plastyków w III Ogólnopolskiej Wystawie Plastyków w Warszawie ${ }^{57}$, zasługach artystów podczas Międzynarodowych Targów Poznańskich ${ }^{58}$. W gazecie znalazło się również miejsce dla plastyków-amatorów, którzy w latach powojennych organizowali wystawy własnych prac, np. „Wiosenny salon”59.

Równie wiele miejsca w gazecie poświęcano artykułom dotyczącym życia naukowego w Łodzi. Po roku 1945 w mieście powstawały uczelnie wyższe tj. Uniwersytet Łódzki, Politechnika Łódzka, Państwowa Wyższa Szkoła Sztuk Plastycznych w Łodzi. Wszystko to skrupulatnie zostało odnotowane $\mathrm{w}$ dzienniku ${ }^{60} \mathrm{z}$ dokładnymi opisami organizacji uczelni wyższych ${ }^{61}$, a wszelkie późniejsze dokonania łódzkich naukowców były śledzone na bieżąco. Początek każdego roku odznaczał się wypowiedziami rektorów wszystkich wyższych uczelni, którzy mówili o kierunku rozwoju uczelni oraz o osiągnięciach w roku ubiegłym. I tak w 1953 roku rektor Politechniki Łódzkiej prof. dr. Bolesław Konorski poinformował czytelników o planowanej budowie pawilonu dla wydziału włókienniczego oraz przejęciu gmachu przy ul. Gdańskiej z przeznaczeniem na wydział chemii spożywczej6 ${ }^{62}$.

W archiwalnych numerach „Dziennika Łódzkiego” odnajdziemy informacje na temat pierwszego w Polsce doktoratu z dziedziny filmu, który otrzymał w 1950 roku Władysław Jewsiewicki ${ }^{63}$. Gazeta pisała również o trzech pierwszych doktoratach honorowych (honoris causa) nadanych przez Uniwersytet Łódzki (otrzymali je dr Fryderyk Joliot-Curie, dyr. Alfred Schimdt-Respringer i Julian Tuwim $)^{64}$ czy habilitacjach uzyskanych na Uniwersytecie Łódzkim ${ }^{65}$. Informowano o uroczystościach uczelnianych m.in.

${ }_{56}$ Z. Nowicki, Plastycy łódzcy pogłębiają walkę z kultem formy, „Dziennik Łódzki”, 1951, nr 16, s. 2.

${ }^{57}$ Z. Nowicki, Ku sztuce godnej wielkiej epoki. Łódzka plastyka na III Ogólnopolskiej Wystawie, „Dziennik Łódzki”, 1953, nr 2, s. 4.

${ }^{58}$ Z. Nowicki, Sukces łódzkich plastyków na MTP, „Dziennik Łódzki” 1949, nr 130, s. 3.

59 Z. Nowicki, Wystawa prac plastyków-amatorów członków Związków Zawodowych, „Dziennik Łódzki” 1949, nr 96, s. 3.

${ }^{60}$ W. Orłowski, Inauguracja roku akademickiego na Uniwersytecie Łódzkim, „Dziennik Łódzki” 1946, nr 14, s. 2.; S. Brycz, Alma Mater łódzka, „Dziennik Łódzki” 1946, nr 10, s. 3; W. Orłowski, Uniwersytet duma robotniczej Łodzi. Rozmowa z rektorem UŁ. prof. dr. Kotarbińskim, „Dziennik Łódzki” 1946, nr 13, s. 1.

${ }^{61}$ Organizacja Uniwersytetu $w$ Łodzi, „Dziennik Łódzki” 1945, nr 10, s. 4.

62 „Dziennik Łódzki” 1953, nr 1, s. 6.

${ }^{63}$ Pierwszy w Polsce doktorat $z$ dziedziny filmu, „Dziennik Łódzki” 1950, nr 94, s. 3.

${ }^{64} \mathrm{Fr}$. Joliot, A. Schmid-Respringer i J. Tuwim pierwszymi doktorami honoris causa Uniwersytetu Łódzkiego, „Dziennik Łódzki” 1949, nr, s. 2.

${ }^{65}$ Habilitacje na Uniwersytecie Łódzkim, „Dziennik Łódzki” 1948, nr 135, s. 5. 
o rocznicach powstania Uniwersytetu Łódzkiego ${ }^{66}$, bibliotece Uniwersytetu Łódzkiego ${ }^{67}$, planach utworzenia miasteczka studenckiego ${ }^{68}$, jubileuszu rektora prof. Tadeusza Kotarbińskiego, otrzymania pierwszego sztandaru przez uniwersytet ${ }^{69}$, powstaniu zakładów endokrynologii i immunologii, prowadzonych zapisach na Politechnikę Łódzką ${ }^{70}$, współpracy wykładowców Uniwersytetu Łódzkiego z Zakładem Narodowym im. Ossolińskich, które ,jako wydawnictwo typu humanistycznego, publikujące dzieła z zakresu literaturoznawstwa, językoznawstwa, różnych działów historii - politycznej, gospodarczej i sztuki, dalej: bibliografie, najwybitniejsze dzieła klasyków polskich i obcych oraz pamiętnikarzy, zainteresowało się przede wszystkim pracami Zakładu Historii Literatury Polskiej i Instytutu Historii Uniwersytetu Łódzkiego"71.

Inne $\mathrm{z}$ informacji, jakie można znaleźć $\mathrm{w}$ „Dzienniku Łódzkim” to m.in. krótkie notatki o różnego rodzaju odczytach. I tak np. „Czytelnik” zorganizował w 1948 roku odczyt z serii Romantyzm polski skierowany do maturzystów ${ }^{72}$, a w siedzibie firmy Ferrum zainteresowani mogli wysłuchać referatu pt. „Udział Polaków w Wiośnie Ludów”" jennych były bardzo popularne. Na łamach „Dziennika Łódzkiego” codziennie można było znaleźć kilka informacji o organizowanych spotkaniach autorskich, referatach lub zebraniach na tematy różnorakie od tematów historycznych, poprzez medyczne, a na typowo rozrywkowych kończąc.

Łódzka gazeta postawiła sobie za cel prowadzenie akcji propagandowej, mającej za zadanie wpojenie społeczeństwu konieczności edukacji. Na łamach „Dziennika” informowano o otwarciu studium scenopisarskiego ${ }^{74} \mathrm{czy}$ szkoły dyrygentów-amatorów ${ }^{75}$. Z tych artykułów czytelnik dowiadywał się, jak będzie wyglądać nauczanie w wybranej szkole oraz gdzie należy zgłaszać chęć udziału w szkoleniach.

${ }^{66}$ Sprawa łódzki uczelni, „Dziennik Łódzki” 1953, nr 11, s. 3.

${ }^{67}$ Dziwolag łódzki czyli biblioteka, „Dziennik Łódzki” 1953, nr. 15, s. 4.

${ }^{68}$ Łódź przyszłości: miasteczko uniwersyteckie, „Dziennik Łódzki” 1953, nr 15, s. 4.

${ }^{69}$ W. Orłowski, Dwa wydarzenia w życiu UŁ. Jubileusz rektora Kotarbińskiego $i$ wręczenie sztandaru uczelni, „Dziennik Łódzki” 1948, nr 124, s. 3.

70 Zapisy na Politechnikę Łódzką, „Dziennik Łódzki” 1949, nr 143, s. 6.

71 J. Trzynadlowski dr, Współpraca wydawnicza Ossolineum z łódzkim ośrodkiem naukowym, „Panorama - dodatek niedzielny Dziennika Łódzkiego” 1953, nr 1, s. 1.

72 Niedzielny odczyt w „Czytelniku”, „Dziennik Łódzki” 1948, nr 111, s. 5.

73 „Dziennik Łódzki” 1948, nr 63, s. 5.

${ }^{74}$ W. Orłowski, „Zaślubiny” filmu z literaturą. Otwarcie studium scenopisarskiego w Łodzi, „Dziennik Łódzki” 1948, nr 111, s. 3.

${ }^{75}$ Jeżeli masz talent - proszę bardzo. Szkoła dyrygentów-amatorów w Łodzi, „Dziennik Łódzki" 1948 , nr 126, s. 5. 
Propagowanie edukacji przez „Dziennik Łódzki” odbywało się również poprzez krótkie informacje-ogłoszenia, dotyczące organizacji wszelkiego rodzaju kursów doszkalających organizowanych przez różne instytucje: m.in. Ośrodek Szkolnictwa Ministerstwa Poczt i Telegrafów organizował kurs teletechników ${ }^{76}$, Zarząd Wojewódzki Związku Samopomocy Chłopskiej zorganizował kurs dla instruktorów gminnych ${ }^{77}$, Instytut Przemysłowo-Rzemieślniczy przygotował kurs dla inżynierów i budowniczych uprawnionych ${ }^{78}$, inspektorat szkolny w Łodzi w trosce o wychowanie dzieci i młodzieży zorganizował kursy przeszkoleniowe dla kierowników wszystkich łódzkich szkół powszechnych ${ }^{79}$.

„Dziennik Łódzki” informował czytelników o konferencjach, które odbywały się w Łodzi, m.in. o konferencji gospodarczej, w której wzięli udział delegaci zarządów rad zakładowych ${ }^{80}$, czy konferencji poświęconej radiofonii, na której zebrani zostali poinformowani o „aktualnych zagadnieniach radiofonii, omówić dotychczasowy program oraz plany na przyszłość"s1. Pisano o powstających w Łodzi Klubie Profesorów Wyższych Uczelni, mieszczącym się wówczas w lokalu przy ul. Piotrkowskiej $78^{82}$ i Klubie Inteligencji Pracującej, który „stanowił ośrodek łączący przedstawicieli rożnych środowisk inteligenckich, który by jednocześnie stanowił kuźnię ideologii demokratycznej" 83 .

„Dziennik Łódzki” w tamtym okresie nakłaniał do odbudowy kraju. Gazeta budziła lokalny patriotyzm, aktywowała mieszkańców miasta m.in. poprzez zbiórkę pieniędzy na budowę domów akademickich, zbiórkę żywności dla najuboższych, a w późniejszych latach akcję ekologiczną „Zielone świadectwo urodzenia”, w której gazeta namawiała rodziców nowo narodzonych dzieci do upamiętnienia tego wydarzenia poprzez posadzenie drzewa $^{84}$. O tej akcji dziennikarze gazety przypomnieli w 2009 roku, poszukując osób, których rodzice posadzili takie drzewa ${ }^{85}$.

${ }^{76}$ Zakończenie kursu teletechników w Łodzi, „Dziennik Łódzki” 1948, nr 114, s. 5.

${ }_{77}$ Kurs instruktorów gminnych $w$ Łodzi, „Dziennik Łódzki” 1948, nr 63, s. 5.

${ }^{78}$ Kurs przygotowawczy do egzaminu dla inżynierów i budowniczych uprawnionych, „Dziennik Łódzki" 1948, nr 132, s. 5.

${ }^{79}$ Kursy dla kierowników szkół powszechnych w Łodzi, „Dziennik Łódzki” 1948, nr 49, s. 3.

${ }^{80}$ Polpress, Konferencja gospodarcza w Łodzi, „Dziennik Łódzki” 1945, nr 8, s. 3.

${ }^{81}$ Konferencja poświęcona radiofonii, „Dziennik Łódzki” 1946, nr 20, s. 8.

82 Otwarcie Klubu Profesorów w Łodzi, „Dziennik Łódzki” 1948, nr 49, s. 3.

83 Otwarcie klubu inteligencji, „Dziennik Łódzki” 1946, nr 130, s. 3.

${ }^{84}$ J. Mikosz, dz. cyt., s. 18.

85 P. Patora, Kto z Państwa ma „Zielone świadectwo urodzenia”? [w:] Dziennik Łódzki [online], [dostęp: 04.07.2013]. Dostępny w WWW: http://www.dzienniklodzki.pl/artykul/136890,kto-zpanstwa-ma-zielone-swiadectwo-urodzenia,id,t.html 
„Dziennik Łódzki” angażował do współpracy wybitnych naukowców, znanych i cenionych literatów, ludzi kultury, sztuki i działaczy gospodarczych. Na łamach gazety można odnaleźć artykuły opatrzone nazwiskami takimi jak: Tadeusz Kotarbiński, Józef Chałasiński, Stefania Skwarczyńska, poeci - Kazimierz Brandys czy Jerzy Wyszomirski. Pismo pełniło funkcję nie tylko informacyjną, ale było również inicjatorem spotkań $\mathrm{z}$ aktorami, hobbystami. Redakcja organizowała także dyskusje, spotkania teatralne, maratony filmowe i wycieczki po Łodzi.

Z analizy artykułów „Dziennika Łódzkiego” z pierwszych lat powojennych wynika, że życie kulturalne w Łodzi w tamtym okresie było bujne jak na tamte czasy. Istniało kilkanaście kin m.in. Świt, Wisła, Młoda Gwardia, Polonia, Bałtyk. Działało kilkanaście teatrów, z których do czasów dzisiejszych zostało zaledwie kilka, m.in. Teatr Powszechny, Nowy, czy im. Jaracza. Teatry w owym okresie działały bardzo prężnie, a każda premiera teatralna czy sukces aktorski były skrupulatnie odnotowywane w „Dzienniku Łódzkim”. Aby zachęcić mieszkańców do odwiedzania muzeów, kin, teatrów czy wystaw proponowano bilety zniżkowe dla określonych grup np. osób należących do Związków Zawodowych, zrzeszeń, spółdzielni itp.

„Dziennik Łódzki” w latach powojennych pokazywał Łódź, jako miasto niezwykle rozwinięte pod względem kulturalnym oraz naukowym. Świadczą o tym chociażby tytuły artykułów takie jak: Łódź - centrum kulturalnym, Jedyne w Polsce placówki naukowe, Młoda uczelnia wielkie nazwiska, Łódź przyszłości: miasteczko uniwersyteckie. W samych tekstach zamieszczanych w „Dzienniku” wiele jest sformułowań świadczących o potędze kulturalnej i naukowej Łodzi w pierwszych latach powojennych. Jeden $z$ artykułów autorstwa Jerzego Szwajcera ${ }^{86}$ zamieszczonych $w$ gazecie rozpoczyna się słowami: „Łódź, która po zniszczeniu Warszawy ambitnie przejęła tradycje kulturalnego centrum Polski, szczyci się w tej chwili (...)"87.

Należy jednak pamiętać, że ze względu na wszechobecną cenzurę i ówczesną politykę państwa, faktyczny wizerunek ówczesnej Łodzi mógł być nieco inny niż przedstawiany w gazecie. Obowiązujący w prasie okresu stalinowskiego model optymistycznego ukazywania codziennego życia wykluczał publikację poważnych, a jednocześnie niekorzystnych propagandowo artykułów. W cytowanym wyżej artykule Grzegorza Mnicha przeczytać można o tekstach, które ze względu na swoją tematykę, nie zostały dopuszczone do druku. Teksty te omawiały problemy społeczne występujące w danym okresie

${ }^{86}$ Jerzy Szwajcer (1892-1967) - polski karykaturzysta, rysownik, dziennikarz, pseud. Jotes.

${ }^{87}$ Jotes, dz. cyt., s. 7. 
np. bieda wśród mieszkańców czy bezrobocie. Artykuły te nie miały szans na zamieszczenie w prasie. Analizując teksty mówiące o życiu kulturalnym i naukowym Łodzi w pierwszych latach powojennych, trudno dopatrzyć się tekstów krytycznych, nacechowanych niepokojącymi informacjami. Pomijano w gazecie tematykę mogącą wywołać niepokoje wśród mieszkańców lub opisującą zaistniały problem. Świat przedstawiony na łamach „Dziennika Łódzkiego” może wydawać się wyidealizowany. Z pewnością zarówno kultura, jak i nauka w powojennej Łodzi, rozwijały się bardzo prężnie, szczególnie do roku 1948. Miało na to wpływ tworzenie wyższych uczelni, organizowanie teatrów i kin. Jednak trudno uwierzyć, aby przez cały ten czas nie wynikł żaden problem lub nieprzyjemna sprawa. Przeciętny czytelnik ówczesnej łódzkiej prasy nie widział śladów cenzorskich ingerencji. Każdy odrzucony fragment zastępowano poprawionym bądź nowym tekstem. Dziś, z perspektywy czasu, aby rzetelnie określić kształt ówczesnej Łodzi, należy pamiętać o uwarunkowaniach historycznych, aby nie uzyskać nieprawdziwego, wyretuszowanego obrazu społeczeństwa i jego problemów. Adam Ochocki w swej książce napisał zdanie o „Dzienniku Łódzkim”, które w pełni podsumowuje gazetę, jaką był dziennik w latach powojennych: „Kokietował sfery rzemieślnicze, licznie jeszcze reprezentowaną prywatną inicjatywę, zamieszczał sporo ogłoszeń, nekrologii z literkami ś.p., co razem sprawiało wrażenie neutralnej gazety, nie mieszającej się do spraw polityki - tej przez małe i przez duże „p" ${ }^{\text {"88. }}$.

\section{Abstract \\ Cultural and scientific life of Lodz presented in „Dziennik Łódzki” in the years $1945-1953$}

"Dziennik Łódzki" from the postwar period is for the present-day researchers valuable source of information. apart from the news from Poland and the World, this paper contained a lot of information about science and cultural life of Lodz. repertoire and art review, radio programs, concert information, films, performances and museum exhibitions, invitations for readings, science meetings, articles about developments and works of science environment in Lodz are only a small part of news printed in "Dziennik Łódzki" but depicting the cultural and scientific life of Lodz in the years 1945-1953.

${ }^{88}$ A. Ochocki, dz. cyt., s. 27. 